\title{
Eksperimental Pengaruh Variasi Sudut Ulir Pada Turbin Ulir (Archimedean Screw) Pusat Pembangkit Listrik Tenaga Mikro Hidro Dengan Head Rendah
}

\author{
Made Agus Trisna Saputra ${ }^{1}$, Antonius Ibi Weking ${ }^{2}$, I Wayan Artawijaya ${ }^{3}$
}

[Submission: 19-01-2019, Accepted: 12-04-2019]

\begin{abstract}
Indonesia has a lot of potential energy both conventional (Non Renwable) and renewable energy. The potential energy thast is mostly used in the area of Indonesia still uses energy in the form of fossil fuels (coal, natural gas and petroleum). At present, the uses of fossil energy reach $75 \%$ and will continue to increase. To reduce thye uses of fossial energy, some studies were conducted realted to renewable energy such as micro hydro. The working principle of micro hydro power plants utilises thye potential energy of water that is converted into electrical energy. The research has been, ade a modeling of micro hydro power plants using screw turbines (Archimedea Screw) with variationsof the blade angle turbine which was starting from the angle $24^{0}, \mathbf{2 6}^{0}, 28^{0}, 3^{0}$, and $32^{\circ}$. This study aimed at determining the effect of blade angke variations on Archimedean Scew turbines on the output produced. The measurements that conducted in this study include measurement of turbine rotation, generator rotation, voltage, current, and torque produced in the modeling that gas been made. From the results of the study found turbines with $28^{0}$ blade angles produce the best performance. This is influenced by the relationship between the angle of the blade with the optimum turbine slope of $40^{\circ}$, where when water enters the turbine blade blades, water flows right about the blade blade's active point so that the turbine can rotate properly From the measurements that have been carried out using a lamp load of 25 Watt, the highest measurement result are obtained at an angle of $28^{0}$. At $28^{\circ}$ angle it produces a power of 10,8 Watt, a torque of $0,33 \mathrm{Nm}$ and efficiency was $11,6 \%$.
\end{abstract}

Intisari- Indonesia memiliki banyak potensi energi baik energy konevensional (Non Renewbale) maupun energi terbarukan (Renewable Energy). Potensi energi yang kebanyakan digunakan di daerah Indonesia masih menggunakan energi bahan bakar fosil (minyak bumi, gas alam, batu bara, dll). Saat ini penggunaan energi fosil mencapai $75 \%$ dan akan terus meningkat.

\footnotetext{
${ }^{1}$ Mahasiswa, Program Teknik Elektro Fakultas Teknik Universitas Udayana, Banjar Gambang, Desa Mengwi, Kecamatan Mengwi, Kabupaten Badung, Bali 80351 INDONESIA (telp:087761468990; email: trisnasaputra1996@gmail.com)

${ }^{2,3}$ Dosen Progam Studi Teknik Elektro Fakultas Teknik Univeristas Udayana, Jln. Jalan Kampus Bukit Jimbaran 80361 INDONESIA (telp: 0361-703315; fax; 0361-4321; email: tony@unud.ac.id) (artawijaya@ee.unud.ac.id)
}

Untuk mengurangi penggunaan energi fosil maka dilakukan penelitian-penelitian mengenai energi terbarukan (Renewable Energy), seperti mikro hidro. Prinsip kerja PLTMH memanfaatkan energi air yang diubah menjadi energi lisrik. Pada penelitian skripsi ini telah dibuat pemodelan pembangkit lsitrik tenaga mikro hidro menggunakan turbin ulir (Archimedean Scew) dengan variasi sudut blade turbin mulai dari $24^{0}, 26^{0}, 28^{0}, 30^{0}$ dan $32^{0}$. Dilakukannya penelitian ini bertujuan untuk mengetahui pengaruh variasi sudut blade pada turbin Archimedean Screw terhadap daya output yang dihasilkan. Pengukuran yang dilakukan pada penelitian ini meliputi pengukuran putaran turbin, putaran generator, tegangan, arus dan torsi pada pemodelan yang telah dibuat. Dari hasil penelitian didapatkan turbin dengan sudut blade $28^{0}$ menghasilkan performa yang terbaik. Hal ini dipengaruhi oleh hubungan antara sudut blade dengan kemiringan turbin sebesar $40^{\circ}$ yang optimum, dimana pada saat air memasuki bilah-bilah blade turbin, air yang mengalir tepat mengenai titik aktif bilah blade sehingga turbin dapat berputar dengan baik. Dari pengukuran yang telah dilakukan dengan menggunakn beban sebesar 25 Watt didapatkan hasil pengukuran tertinggi pada sudut $28^{0}$. Pada sudut $28^{0}$ menghasilkan daya sebesar 10,8 Watt, torsi sebesar $0,33 \mathrm{Nm}$ dan efisiensi sebesar $11,6 \%$.

Kata Kunci- Archimedean Screw, Effesiensi ,Torsi, PLTMH, Mikro Hidro.

\section{PENDAHULUAN}

Indonesia memiliki banyak potensi energi baik itu energi konvensional (Non renewale) maupun energi terbarukan (renewable). Potensi energi yang kebanyakan digunakan untuk daerah Indonesia masih menggunakan energi konvensional (Non Renewable) berupa bahan bakar fosil (batu bara, gasa alam dana minyak bumi). Pada tahun 2006 kementrian ESDM menyebutkan bahwa cadangan minyak bumi akan habis dalam kurum waktu 23 tahun, gas alam pada kurun waktu 62 tahun, serta batu bara pada kurun waktu 146 tahun [1]. Pemerintah telah menerbitkan Pedoman Pengusaha Pembangkit Tenaga Listrik Skala Kecil melalui Kepmen ESDM No. 1122K/30/MEM/2002 untuk meningkatkan pemanfaatan energi terbarukan untuk pembangkit listrik sampai dengan $1 \mathrm{MW}$ yang diusulkan oleh usaha kecil dan koperasi [2]. Salah satu Pembangkit Listrik tenaga terbarukan yang baik dibangun di Indonesia khususnya adalah Pembangkit Listik Tenaga Mikro Hidro (PLTMH).

Pada penelitiannya dilakukan Syahputra, dkk dilaukan pengujian turbin ulir dengan 4 variasi debit air dan 3 variasi kemiringan dengan sudut $26^{\circ}, 28^{\circ}$ dan $30^{\circ}$. Dari hasil pengujian yang dilakukan didapatkan nilai paling maksimal 
terhadap kerja turbin yaitu pada debit $0,0433 \mathrm{~m} 3 / \mathrm{s}$ dan kemiringan turbin pada $30^{\circ}$. Sehingga didapatkan putaran murni turbin yaitu $91 \mathrm{rpm}$ [3]. Dalam kaitan pemilihan turbin peneliti mengembangkan tentang Pembangkit Listrik Mikro Hidro dengan menggunakan turbin ulir (Archimedean screw). Turbin ini memiliki keuntungn dibandingkan dengan jenis turbin lain, seperti memiliki efisiensi yang tinggi, mudah dalam pemeliharaan dan tidak mengganggu ekosistem ikan. Efisiensi pada sudut turbin dipengaruhi oleh debit air, dimana semakin besar debit air yang diberikan maka efisiensi yang dihasilkan semakin besar [4]. Pada penelitian ini akan dilakukan pengujian pada turbin dengan variasi sudut blade dengan kemiringan poros dan debit air yang optimum untuk mengetahui performa yang dihasilkan.

\section{A. Pengetian PLTMH}

\section{TURBIN PADA PLTMH}

PLTMH adalah suatu pembangkit listrik skala kecil yang menggunakan energi air sebagai penggeraknya, misalnya saluran sungai atau air terjun alam dengan cara memanfaatkan tinggi terjunnya air (head) dan jumlah debit air maupun tekanan airnya. PLTMH merupakan pembangkit listrik tenaga air skala yang memiliki batasan daya sebesar $5 \mathrm{~kW}-1 \mathrm{~mW}$ per unitnya. Terdapat juga beberapa batasan daya untuk PLTMH yaitu $120 \mathrm{kw}$ hingga $200 \mathrm{~kW}$. Prinsip kerja dari pembangkit ini, yaitu memanfatkan ketinggian jatuh air dan debit air pada sungai atau air terjun. Aliran air akan mengalir melalui intake yang akan diteruskan pada saluran pembawa hingga menuju penstock. Pada air yang dialirkan akan memutar turbin sehingga menghasilkan energi mekanik sehingga turbin berputar dan memutar generator. [5].

\section{B. Turbin Air}

Turbin air digunakan untuk merubah energi air menjadi energi putar. Turbin yang dihubungkan dengan beberapa pulley digunakan untuk memutar generator. Terdapat 3 faktor penting dalam pemilihan jenis turbin, yaitu debit air, ketinggian jatuh air serta kecepatan putaran generator. Turbin air diklasifikasikan dengan beberapa cara. Hal yang utama dalam dalam klasifikasi turbin, yaitu berdasarkan cara turbin merubah energi potensial menjadi energi mekanik. Turbin air diklasifikasikan menjadi 2, yaitu :

1) Turbin Reaksi

Turbin reaksi memanfaatkan energi potensial menjadi energi mekanik. Sudut pada turbin reaksi memiliki profil khusus sehingga menyebabkan penurunan selama melalui sudut. Perbedaaan tekanan memberikan gaya pada sudut sehingga menyebabkan runner dapat berputar. Turbin yang termasuk dalam turbin reaksi adalah, turbin francis, turbin Kaplan, dan turbin propeller.[6].

\section{2) Turbin Impuls}

Turbin Impuls merupakan turbin yang memanfaatkan energy potensial yang diubah menjadi energi kinetik dengan nozzle. Air yang dikeluarkan dari nozzle memiliki tekanan yang sangat tinggi unuk membentur sudut turbin. Air yang membentur sudut turbin, kecepatan air berubah sehinngga terjadi perubahan momentum dan menyebabkan turbin berputar. Turbin yang termasuk dalam turbin impuls, antara lain Turbin pleton, turbin turgo, dan turbin michell-bankin (turbin cross flow atau assberger).

\section{3) Turbin Archimedean Screw}

Turbin Ulir atau Archimedean Screw merupakan turbin yang sudah ada pada zaman kuno yang dimanfaatkan sebagai pompa air untuk pengairan. Seiring dengan krisis energi dan terbatasnya potensi energi air dengan head yang tinggi, maka pada tahun 2007 seorang insinyur memodifikasi pompa Archimedes yang dibalik dan membiarkan air mengendalikan pompa dan pada ujung pompa dipasang generator, maka dapat menghasilkan listirk selama generator tersebut tidak terendam air atau terkena air. Turbin ulir ini dapat digunakan pada head rendah. Sudut blade pada turbin ulir biasanya ditetapkan pada sudut $22^{\circ}$. Turbin ulir memiliki prinsip kerja, dimana tekanan air yang melalui bilah-bilah sudut turbin mengalami penurunan tekanan sejalan dengan penurunan kecepatan air akibat adanya hambatan dari bilah-bilah sudut turbin maka tekanan air akan memutar turbin dan secara bersamaan memutuar generator.

Berikut merupakan keuntungan turbin Archimedes screw dibandingkan turbin lain, yaitu:

a) Efisiensi tinggi.

b) Simple dan reliable.

c) Ekosistem ikan tidak terganggu

d) Jika dioperasikan dalam putran rendah maka dapat menyebabkan umur turbin bertahan lama

e) Perawatan yang mudah

f) Pengoperasian yang mudah dan biaya yang murah.

Berikut merupakan persamaan yang digunakan dalam menentukan sudut dari turbin ulir [7]:

$$
\alpha=R_{0} \frac{2 \pi}{\Lambda}
$$

Dimana:

$$
\begin{aligned}
& \alpha=\text { sudut blade } \\
& R_{0}=\text { jari-jari turbin } \\
& \Lambda=\text { jarak antar ulir }
\end{aligned}
$$

\section{Kriteria Pemilihan Turbin}

Kriteria pemilihan turbin ditentukan oleh kelebihan dan keurangan turbin tersebut. Pemilihan jenis turbin dapat dengan memperhitungkan parameter khusus yang mempengaruhi pengoperasian turbin. [8]. Berikut parameter yang mempengaruhi opersai turbin, yaitu:

A. Faktor tinggi jatuhnya air dan debit yang akan digunakan untuk operasi turbin, dimana semkain miring maka kemungkinan untuk ditemukannya head yang cukup untuk PLTMH semakin besar Derajat kemiringan dapat ditentukan dengan persamaan berikut:

$$
\begin{aligned}
& \tan \alpha=y / x \\
& \alpha=\tan ^{-1}(y / x)
\end{aligned}
$$

B. Faktor daya (power) yang berhubungan dengan head dan debit air yang digunakan. Berikut merupakan persamaan yang digunakan untuk menghitung debit air [9] : 


$$
\text { Debit }=\frac{\text { volume bejana }}{\text { waktu untuk memenuhi bejana }}
$$

Gambar 1 menunjukkan tahapan penelitian yang akan dilakukan, mulai dari perancangan sistem, pengumpulan data dan uji coba pemodelan yang telah dibuat.

C. Kecepatan turbin yang akan ditransmisikan ke genrator. Untuk torsi dapat dilakukan dengan perhitungan sebagai berikut [10] :

$$
\begin{aligned}
& P=T .2 \pi \cdot \frac{N}{60} \\
& T=\frac{P}{2 \pi \frac{n}{60}} \\
& n=60 \frac{P}{T .2 \pi}
\end{aligned}
$$

Dimana:

$$
\begin{aligned}
& \mathrm{T}=\text { Torsi }(\mathrm{Nm}) \\
& \mathrm{P}=\text { Daya }(\mathrm{Kw}) \\
& \mathrm{N}=\text { Kecepatan Putaran }(\mathrm{rpm}) \\
& \text { D. Daya Hidrolis dan Efisiensi }
\end{aligned}
$$

\section{Daya Hidrolis dan Efisiensi}

Pembngkitan tenaga listirk dengan menggunakan tenaga air merupakan suatu perubahan tenaga dari tenaga air dan ketinggian jatuh air serta debit air tertentu yang diubah menjadi tenaga listrik, dengan menggunakan turbin air dan generator. Daya yang dihasilkan dapat dihitung berdasarkan persamaan berikut [11]:

$$
P=\rho \cdot Q \cdot g \cdot H
$$

Dimana:

$$
\begin{aligned}
& \mathrm{P}=\text { Daya hidrolis } \\
& \rho=\text { Massa Jenis Fluida } \\
& \mathrm{Q}=\text { Debit } \\
& \mathrm{G}=\text { Gaya Gravitasi } \\
& \mathrm{H}=\text { head }
\end{aligned}
$$

Daya yang dihasilkan generator dapat dihitung menggunakan persamaan berikut:

$$
\text { Pout }=\text { V.I }
$$

Efisiensi sistem merupakan kemampuan peralatan pembangkit untuk mengubah energi kinetik air yang mengalir menjadi energi listrik. Untuk menghitung efisiensi dapat digunakan rumus sebagai berikut [12]:

$$
\eta=\frac{P_{\text {out }}}{P_{\text {in }}} 100 \%
$$

\section{Dimana :}

$\eta_{\text {PLTMH }}=$ Efisiensi sistem PLTMH

$P_{\text {out }}=$ Daya Hidrolis

$P_{\text {in }}=$ Daya Generator

\section{METODE PENELITIAN}

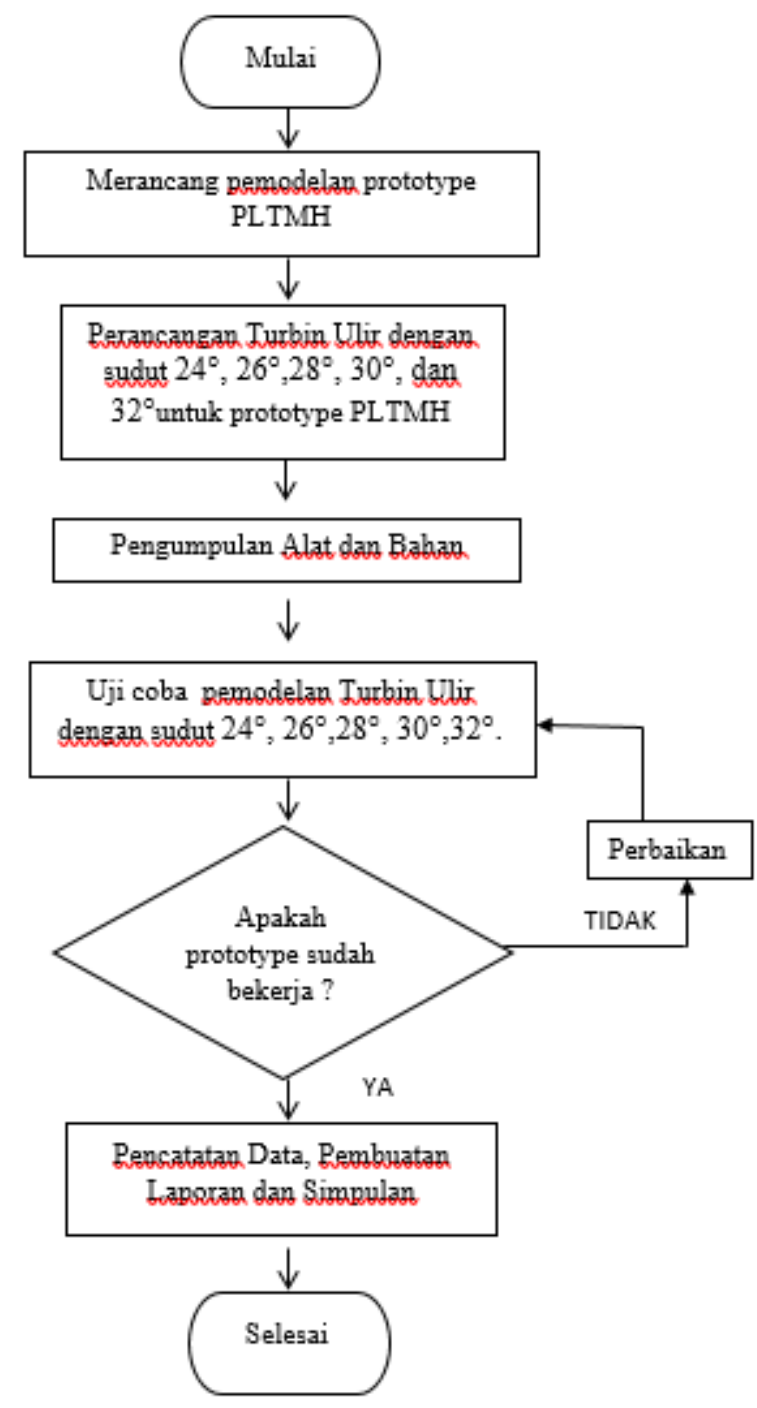

Gambar 1. Flow Chart alur penelitian

\section{A. Merancang Pemodelan Prototype PLTMH}

Pada perencanaan sistem PLTMH ini dilakukan perancangan desain pemodelan PLTMH yanga akan dibuat seperti desain rangka PLTMH, desain, turbin yang digunakan, desain rumah turbin, desain box penampungan air dan desain penstock yang akan dilakukan pada pemodelan sistem PLTMH. Tabel 1 merupakan data parameter-parameter yang akan digunakan dalam pemodelan sistem PLTMH dalam penelitian ini. 
TABEL I

PARAMETER PLTMH

\begin{tabular}{|c|c|}
\hline Parameter & Value \\
\hline Volume Box & $220 \mathrm{~L}$ \\
\hline Head & $150 \mathrm{~cm}$ \\
\hline Panjang Pipa & $150 \mathrm{~cm}$ \\
\hline Diameter Pipa & $3,2 \mathrm{~cm}$ \\
\hline
\end{tabular}

\section{B. Perencanaan Turbin Ulir Archimedean Screw}

Pada perencanaan turbin dilakukan perancagan desain turbin ulir (Archimedean Screw), seperti besar pipa poros yang akan digunakan, memilih plat besi yang akan digunakan sebagai sirip blade. Table 2 menunjukkan parameterparameter yang akan digunakan dalam pembuatan turbin Archimedean Screw yang akan digunakan dalam penelitian ini.

TABEL II

SPESIFIKASI TURBIN ARCHIMEDEAN SCREW

\begin{tabular}{|c|c|}
\hline Parameter & Value \\
\hline Sudut blade turbin & $24^{0}, 26^{0}, 28^{0}, 30^{\circ}$, dan $32^{\circ}$ \\
\hline Jari-jari sudut & $10 \mathrm{~cm}$ \\
\hline Jarak antar blade & $21 \mathrm{~cm}$ \\
\hline Lebar screw & $10 \mathrm{~cm}$ \\
\hline Diameter poros turbin & $6 \mathrm{~cm}$ \\
\hline Panjang poros turbin & $150 \mathrm{~cm}$ \\
\hline Diameter turbin & $26 \mathrm{~cm}$ \\
\hline
\end{tabular}

\section{Pengumpulan Alat dan Bahan}

Komponen-komponen yang digunakan dalam pembuatan pemodelan pembangkit listrik tenaga mikro hidro dengan turbin archimedean screw ini meliputi box air, besi, generator, pipa dan pompa.

\section{Perancangan Pemodelan PLTMH mengunakan Turbin} Archimedean Screw

Perancangn pemodelan pemabangkit listrik tenaga mikro hidro ini terdiri dari beberapa komponen inti seperti, Turbin Archimedean screw, Generator, rangka pemodelan pembangkit, box air, pompa diesel, dan juga gear yang digunakan untuk menghubungkan turbin dengan generator. Berikut merupakan desain dari pemodelan pemnamgkit listrik tenaga mikro hidro dengan turbin Archimedean screw.

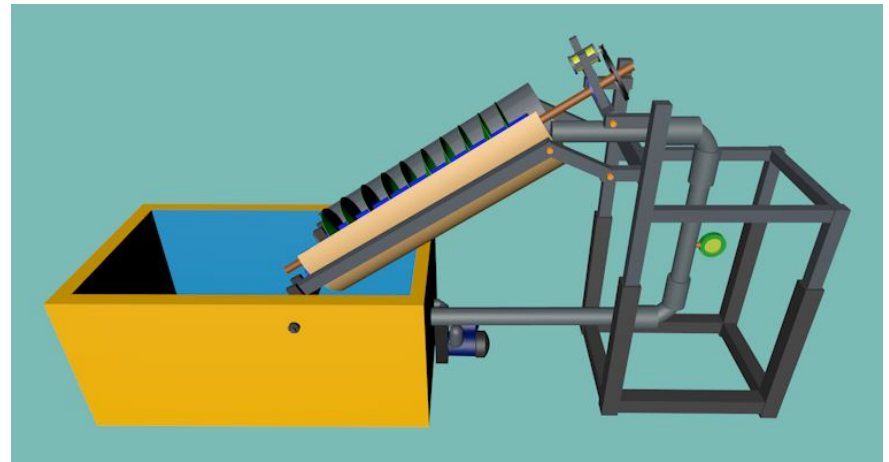

Gambar 2. Desain pemodelan PLTMH

\section{E. Uji Coba Pemodelan Turbin Ulir}

Pengujian pada pemodelan pembangkit listrik tenaga mikro hidro dengan turbin Archimedean Screw ini bertujuan untuk mengetahui performa pembangkit listrik dengan turbin Archimedean screw yang telah dirancang. Cara kerja dari pengujian pemodelan ini, yaitu air yang ditampung pada box air akan disedot menggunakan pompa menuju pipa (penstock). Air yang telah disedot menggunakan pompa dialiri melalui pipa menuju turbin. Aliran air akan memasuki bilah-bilah blade dan mengenai titik aktif pada blade dan menimbulkan gaya berat air dan beda tekanan sehingga dapat mendorong blade dan memutar turbin. Sebelumnya turbin dan genetrator telah dikopel dengan gear box dengan ratio 1:12 sehingga secara spontan turbin juga mengakibatkan generator ikut berputar. Pada generator telah dihubungkan dengan Avometer yang berfungsi untuk mengukur tegangan dan arus yang dihasilkan.

\section{F. Pencatatan Data Hasil Pengukuran dan Menganalisa Data hasil Pengukuran. \\ Setelah dilakukan pengujian pada pemodelan Pembangkit} Listrik Tenaga Mikro Hdiro dengan Turbin Ulir (Archimedean Screw), maka didapatkan hasil output meliputi putaran turbin, putaran generator, tegangan, arus dan daya kemudian dilakukan analisa data mengenai pengaruh variasi sudut blade turbin terhadap torsi, pengaruh variasi sudut blade turbin, terhadap efisiensi, pengaruh variasi sudut turbin terhadap tegangan, arus dan daya generator, pengaruh variasi sudut blade turbin terhadap putaran generator dan putaran turbin dengan menggunakan turbin Ulir (Archimedean Screw) pada Pusat Pembangkit Listrik Tenaga Mikro Hdiro head rendah. Dalam penelitian ini pengambilan data dilakukan sebanyak 5 kali pada setiap parameter, hal ini dilakukan guna didapatkan data yang akurat.

\section{HASIL DAN PEMBAHASAN}

A. Realisasi Pemodelan Pembangkit Listrik Tenaga Mikro Hidro mengunakan Turbin Ulir (Archimedean Screw)

Gambar 3 merupakan realisasi pemodelan pembangkit listrik tenaga mikro hidro yang telah dibuat. Pemodelan ini terdiri dari beberapa bagian, seperti box air yang digunakan untuk menampung air, rumah turbin yang berfungsi untuk melindungi air agar tidak keluar turbin, pipa penstock yang berfungsi untuk mengalirkan air, pompa yang digunakan 
utnuk menyedot air dari box air dan menyemprotkan air ke turbin, serta generator.

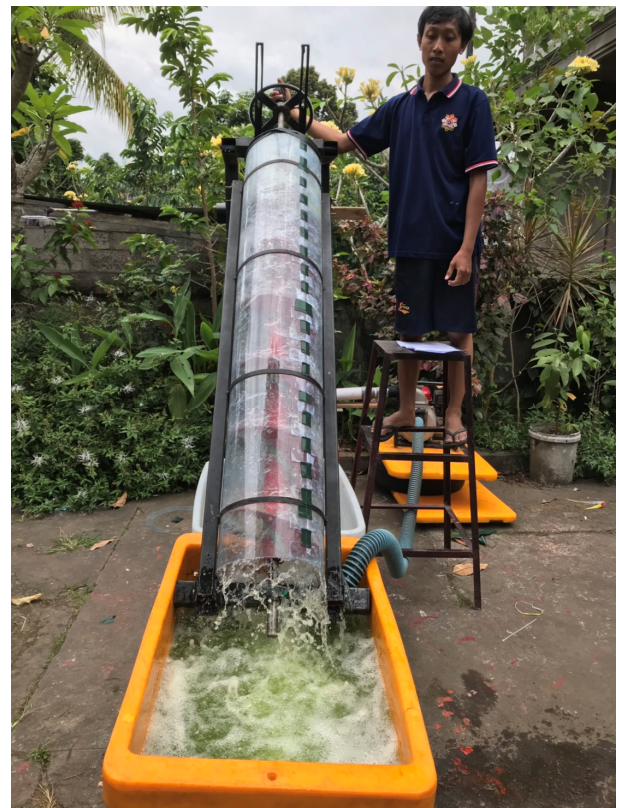

Gambar 3. Realisasi Pemodelan PLTMH

\section{B. Data Hasil Pengukuran}

Prinsip kerja dari pengukuran data pada pemodelan PLMH ini, dimana air yang ditampung dalam box air akan disedot menggunakan pompa diesel yang telah dihubungkan dengan box air dan penstock. Air yang telah disedot akan dialiri menuju penstock yang kemudian tekanan air yang diberikan oleh pompa akan memasuki bilah-bilah turbin dan mengenai titik aktif pada blade turbin sehingga mengakibatkan turbin berputar. Turbin yang berputar secara spontan akan ikut memutar generator yang sudah di kopel. Generator yang berputar telah dihubungkan dengan alat ukur avometer sehingga tegangan dan arus yang dikeluarkan oleh generator dapat diukur langsung.

Tabel 3 merupakan rata-rata dari data yang didapatkan pada saat pengukuran pemodelan pembangkit listrik tenaga mikro hidro dengan turbin Archimedes dengan variasi sudut blade.

TABEL III

DATA HASIL PENGUKURAN

\begin{tabular}{|c|c|c|c|c|c|c|c|c|c|}
\hline \multirow{2}{*}{$\mathrm{N}_{0}$} & \multirow{2}{*}{$\begin{array}{l}\text { Sudut } \\
\text { Blade }\end{array}$} & \multicolumn{2}{|c|}{$\begin{array}{c}\text { Putaran Turbin } \\
(\mathrm{rpm})\end{array}$} & \multirow{2}{*}{$\begin{array}{l}\text { Putaran } \\
\text { Generator } \\
(\mathrm{rpm})\end{array}$} & \multicolumn{2}{|c|}{$\begin{array}{l}\text { Tanpa } \\
\text { Beban }\end{array}$} & \multicolumn{3}{|c|}{ Beban } \\
\hline & & $\begin{array}{l}\text { Sebelum } \\
\text { dikopel }\end{array}$ & $\begin{array}{l}\text { Setelah } \\
\text { dikopel }\end{array}$ & & $\mathrm{V}$ & \begin{tabular}{|l|l}
$I$ & $P$ \\
\end{tabular} & V & I & $\mathrm{P}$ \\
\hline 1 & $24^{\circ}$ & 361 & 210 & 4341 & 111,7 & \begin{tabular}{l|l}
0 & 0
\end{tabular} & 96,7 & 0,0687 & 6,6 \\
\hline 2 & $26^{\circ}$ & 447 & 287 & 5368 & 119,6 & \begin{tabular}{l|l}
0 & 0
\end{tabular} & 111,5 & 0,0735 & 8,2 \\
\hline 3 & $28^{\circ}$ & 581 & 315 & 6972 & 143,5 & $0 \mid 0$ & 135,6 & 0,0821 & 11,1 \\
\hline 4 & $30^{\circ}$ & 392 & 251 & 4706 & 122,6 & \begin{tabular}{l|l}
0 & 0
\end{tabular} & 102,7 & 0,0765 & 7,9 \\
\hline 5 & $32^{\circ}$ & 331 & 197 & 3974 & 81,3 & \begin{tabular}{l|l}
0 & 0
\end{tabular} & 74,5 & 0,0621 & 4,6 \\
\hline
\end{tabular}

Made Agus Trisna Saputra: Eksperimental Pengaruh Variasi Sudut..
Berdasarkan table diatas maka dapat dibuat grafik hubungan antara sudut blade terhadap putaran turbin, putaran generator, arus, tegangan, daya, torsi dan efisiensi.

\section{Hubungan Sudut Blade dengan Putaran Turbin}

Gambar 4 merupakan grafik hubungan antara sudut blade turbin Archimedan screw dengan putaran turbin.

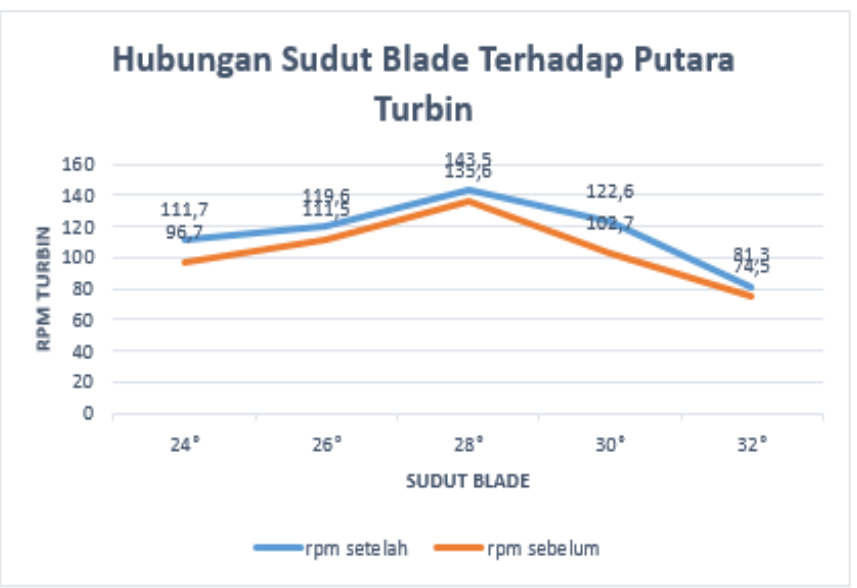

Gambar 4. Grafik hubungan Putaran Turbin

Berdasarkan grafik 4 hubungan sudut kemiringan blade terhadap putaran turbin dengan variasi sudut blade pada turbin yang ditunjukkan pada gambar, dapat diketahui bahwa kecepatan putaran turbin dari sudut $24^{\circ}$ hingga sudut $28^{\circ}$ meningkat. Sedangkan dari sudut $28^{\circ}$ menuju sudut $32^{\circ}$ menurun hal ini dipengaruhi oleh besar sudut pada turbin. Hasil pengukuran putaran turbin pada sudut $24^{\circ}$ dan $26^{\circ}$ tidak begitu baik, hal ini dikarenkan pada saat diberikan tekanan air, aliran air yang diberikan tidak mengenai titik aktif turbin dan membuat putaran turbin menjadi rendah. Hasil pengukuran tertinggi didapatkan pada sudut kemiringan blade $28^{\circ}$ dengan menghasilkan putaran turbin sebelum dikopel dengan generator sebesar $581 \mathrm{rpm}$ dan putaran turbin setelah dikopel sebesar $315 \mathrm{rpm}$

\section{Hubungan Sudut Blade Terhadap Putaran Generator}

Gambar 5 merupakan grafik hubungan antara sudut blade turbin Archimedan screw terhadap putaran generator. 


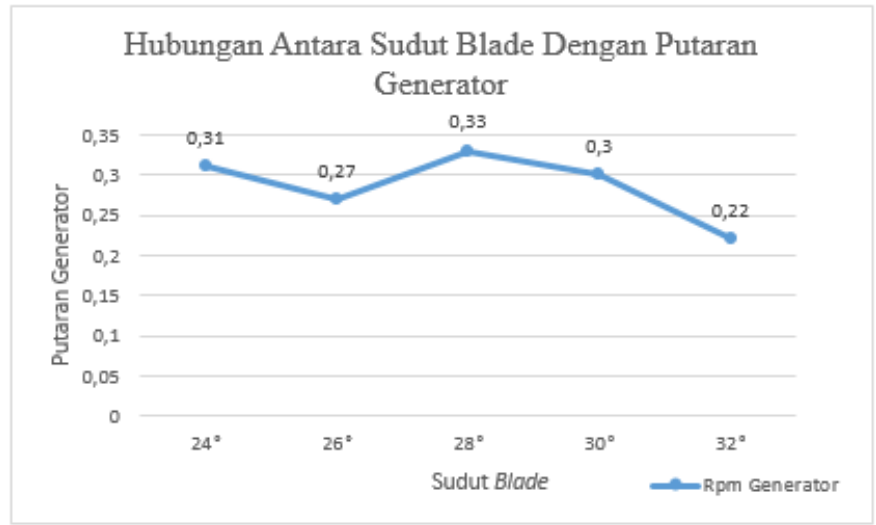

Gambar 5. Grafik hubungan Putaran Generator

Garfik 5 merupakan hasil pengukuran putaran generator ini dilakukan setelah generator dikopel dengan turbin menggunakan gear dengan ratio 1:12 sehingga generator dapat berputar. Hasil pengukuran tertinggi didapatkan pada sudut kemiringan blade $28^{0}$ dengan menghasilkan putaran generator sebesar $6972 \mathrm{rpm}$. Hal ini disebabkan karena putaran turbin pada sudut $28^{\circ}$ merupakan putaran turbin terbesar sehingga putaran generator yang dihasilkan juga besar. Tekanan air yang mengalir memasuki turbin mengenai sisi aktif blade sehingga dapat memutar turbin dan menghasilkan putaran generator yang maksimal. Pada sudut $24^{0}, 26^{\circ}, 30^{\circ}$ dan $32^{0}$ aliran air yang memasuki turbin tidak mengenai sisi aktif turbin sehingga membuat putaran turbin tidak terlalu tinggi sehingga membuat putaran generator tidak maksimal.

\section{E. Hubungan Sudut Blade Terhadap Tegangan}

Gambar 6 merupakan grafik hubungan antara sudut blade turbin Archimedan screw terhadap tegangan

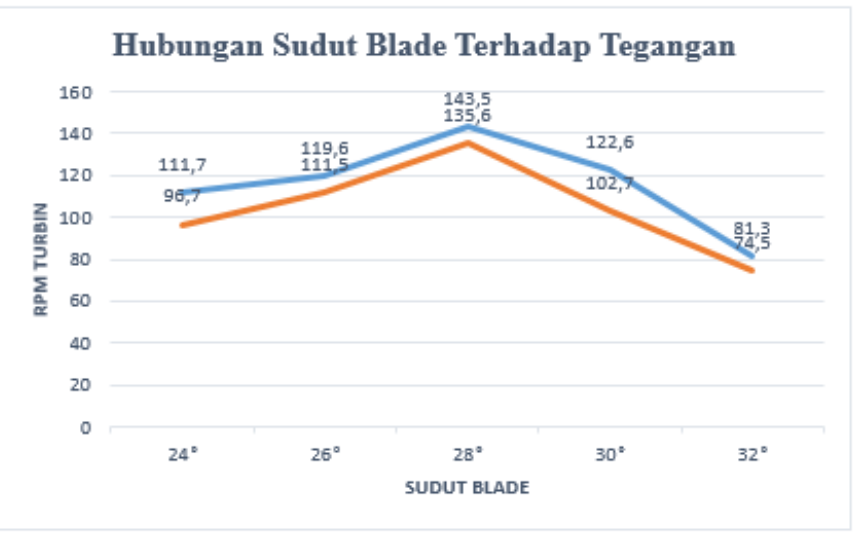

Gambar 6. Grafik Hubungan Tegangan

Gambar 6 merupakan hasil pengukuran tegangan ini dilakukan setelah generator dibebani dengan beban sebesar 25 watt. Hasil pengukuran tertinggi didapatkan pada sudut kemiringan blade $28^{\circ}$ dengan menghasilkan tegangan sebesar 143,5 watt pada saat sebelum dibebani dan menghasilkan tegangan sebesar 135,6 watt setelah diberi beban sebesar 25 watt. Hal ini disebabkan karena putaran turbin pada sudut $28^{0}$ merupakan putaran turbin terbesar sehingga putaran generator yang dihasilkan juga besar sehingga tegangan yang dihasilkan pada saat sebelum dibebani dan berbeban menjadi yang terbaik diantara sudut lain.

F. Hubungan Sudut Blade Terhadap Daya

Gambar 7 merupakan grafik hubungan antara sudut blade turbin Archimedan screw terhadap daya.

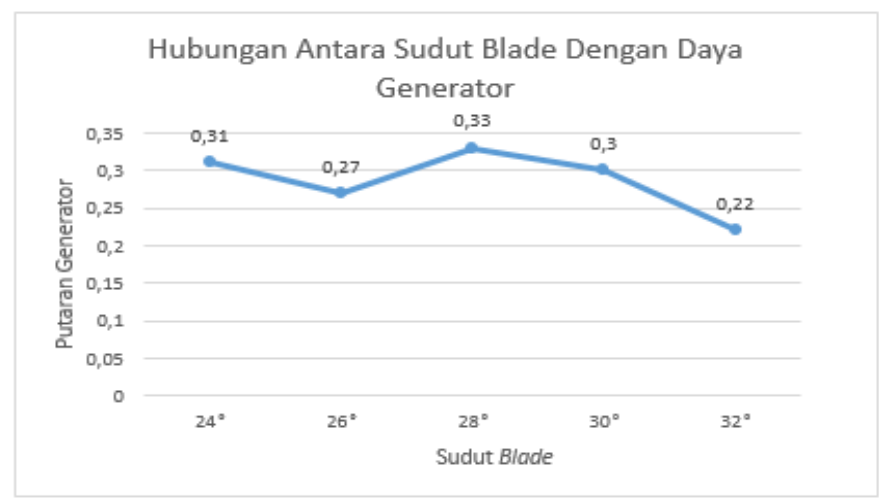

Gambar 7. Grafik Hubungan Daya

Berdasarkan gambar grafik 4.4 hubungan sudut kemiringan blade pada turbin terhadap daya yang dihasilkan, maka dapat disimpulkan bahwa daya tertinggi yang dihasilkan terjadi pada turbin dengan sudut kemiringan blade $28^{0}$, dengan daya sebesar 10,8 watt. Hal ini diakibatkan karena putaran turbin dan putaran generator yang dihasilkan tertinggi diantara sudut yang lain sehingga berpengaruh terhadap daya yang dihasilkan.

\section{G. Hubungan Sudut Blade Terhadap Torsi}

Torsi merupakan besaran gaya yang bekerja pada sebuah benda sehingga menyebabkan benda tersebut berotasi. Pada penelitian ini dilakukan Pengujian terhadap Pemodelan Pembangkit Listrik Tenaga Mikro Hidro dengan variasi sudut kemiringan blade. Berikut merupakan perhitungan untuk mendapatkan torsi:

$$
T=\frac{P}{2 \pi \frac{n}{60}}=\frac{10,8}{2 * 3,14 * \frac{315}{60}}=\frac{10,8}{32,9}=0,33 \mathrm{Nm}
$$

Grafik hasil perhitungan torsi pada pemodelan PLTMH dapat dilihat pada gambar 8 .

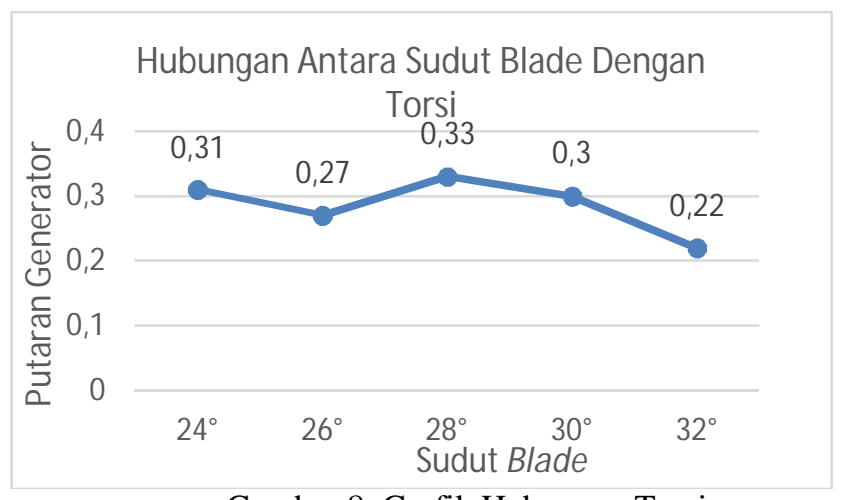

Gambar 8. Grafik Hubungan Torsi 
Grafik 8 merupakan hubungan antara sudut blade dengan torsi dimana dipengaruhi oleh kecepatan putaran turbin. Semakin cepat perputan turbin maka putaran generator yang dihasilkan akan semakin cepat sehingga torsi yang dihasilkan untuk memutar generator semakin cepat. Berdasarkan gambar 4.13 dapat dilihat bahwa torsi yang terbesar terjadi pada sudut $28^{0}$ dengan torsi sebesar $0,33 \mathrm{Nm} 28^{\circ}$, ini terjadi karena putaran turbin pada sudut $28^{0}$ merupakan putaran turbin tercepat.

\section{H. Hubungan Sudut Blade Terhadap Efisiensi}

Berdasarkan pengukuran yang telah dilakukan pada pengujian pemodelan pembangkit lsitrik tenaga mikro hidro dengan turbin Archimedes dengan input variasi sudut kemiringan blade. Maka dapat dilakukan perhitungan untuk mendapatkan efisiensi PLTMH dengan menggunakan persamaan sebagai berikut:

$$
\eta_{\text {PLTMH }}=\frac{11,1}{93,3} \cdot 100 \%=11,8 \%
$$

Grafik hasil perhitungan efisiensi pada pemodelan PLTMH dapat dilihat pada gambar 9

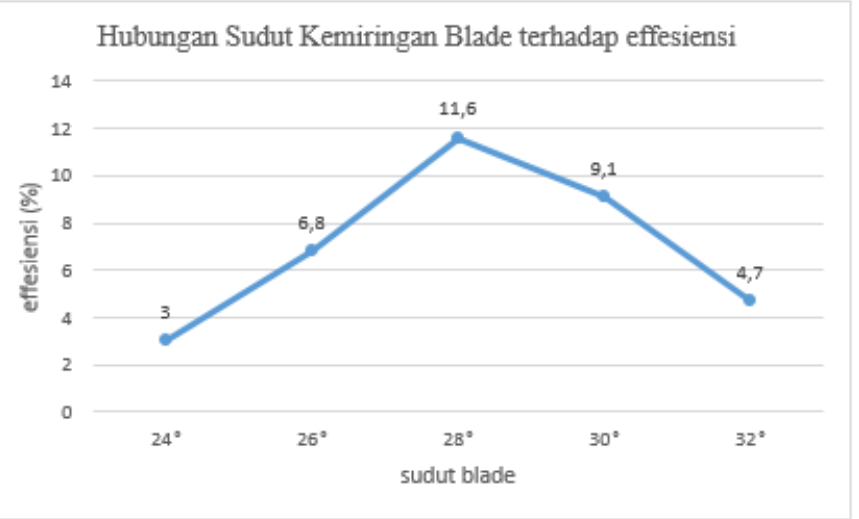

Gambar 9. Grafik Hubungan Efsiensi

Berdasarkan grafik 9 dapat dilihat bahwa pada sudut kemiringan blade $28^{0}$ memiliki efisiensi terbesar, yaitu $11,6 \%$. Hal ini dikarenakan pada sudut $28^{\circ}$ memiliki putaran turbin, putaran generator, tegangan, arus dan daya yang terbaik sehingga berpengaruh terhadap efisiensi yang dihasilkan.

\section{KESIMPULAN}

Hasil Pengujian Pemodelan Pembangkit Listrik Tenaga Mikro Hidro dengan variasi sudut blade pada pemodelan PLTMH dengan Turbin Archimedes bahwa pada sudut blade $28^{0}$ merupakan sudut terbaik dengan menghasilkan putaran turbin sebesar $581 \mathrm{rpm}$ dan $315 \mathrm{rpm}$ pada saat setelah di kopel. Tegangan dan arus yang dihasilkan sebesar 135,6 V pada saat berbeban dan arus sebesar 0,0821 A, sehingga menghasilkan daya output yang terbaik sebesar 11,1 Watt. Torsi sebesar $0,33 \mathrm{Nm}$ dan menghasilkan effesiensi sebesar $11,6 \%$.

\section{REFERENSI}

[1] Setiarso, M.A. Widiyanto, W. Purnomo, S.N. 2016. Potensi Tenaga Listrik dan Penggunaan Turbin Ulir Untuk Pembangkit Skala Kecil di Saluran Irigasi
Banjarcahyana. DINAMIKA REKAYASA Vol. 13 No. 1 (2016), Hal. 18-27.

[2] Havendi, A \& Arnif, I., 2010. Kaji Eksperimental Penentuan Sudut Ulir Untuk Data Perencanaan Turbin Ulir Pada Pusat Listrik Tenaga Mikrohidro (PLTMH) Head Rendah.

[3] T, Syahputra, dkk., 2017. Rancang Bangun Prototipe Pikohidro dengan Menggunakan Turbin Ulir. Darusalam, Bnada Aceh

[4] Kementrin Sumber Daya Alam dan Mineral. Pedoman Pengusaha Pembangkti Listrik Tenaga Mikro Hidro Skala Kecil. ( diaskes 15 September 2018)

[5] Nugroho, Y.S.H., 2015. Panduan Lengkap Membuat Sumber Energi Terbarukan Secara Swadya Edisi 1. CV. ANDI OFFSET, Yogyakarta

[6] Damastuti Anya, P., 1997. Pembangkit Listrik Tenaga Mikro Hidro. Wacana No. 8/Mei - juni 1997.

[7] Susatyo, A., 2003. Perancangan Turbin Pelton. Pusat Penelitian Informatika - LIPI, Bandung

[8] Rorres, C., 2000. The turn Of The Screw: Optimal Design Of an Archimedeam Screw.

[9] Sihombing, E. S., 2009. Pengujian Sudu Lengkap Prototipe Turbin Air Terapung Pada Aliran Sungai. Universitas Sumatera, Medan.

[10] Bahri, A. Jasa, L. Sudarmojo, Y.P. 2017. "Merancang dan Mengimplementasi Modul Praktikum Pembangkit Listrik Tenaga Mikro Hidro di Jurusan Teknik Elektro dan Komputer Universitas Udayana”. Majalah Ilmiah Teknologi Elektro. Vol. 16, No. 02, Mei - Agustus 2017.

[11] Saputra, I.W.B. Weking, A.I, Jasa, L. 2017. "Rancang Bangun Pemodelan Pembangkit Listrik Tenaga Mikro Hidro (PLTMH) Menggunakan Kincir Overshot Wheel”. Majalah Ilmiah Teknologi Elektro. Vol. 16, No. 02, MeiAgustus 2017.

[12] Tohari, M. 2015. Pengujian Unjuk Kerja Turbin Crossflow Skala Laboratorium dengan Jumlah Sudu 20. Sekolah Tinggi Teknik Harapan.

[13] Sihaloho, D.L. 2017. 'Rancang Bangun Alat Uji Model Sistem Pembangkit Listrik Tenaga Mikro Hidro (PLTMH) Menggunakan Turbin Aliran Silang”. Bandar Lampung : Universitas Lampung. 
[Halaman ini sengaja dikosongkan] 